\title{
Physicochemical and Mineral Analysis of Fish Pond Water; Implications for the Environment
}

\section{${ }^{1}$ MGBEMENA, NM; ${ }^{2}$ ILECHUKWU, I; ${ }^{3}$ AMALU, EU; *2ANIEROBI, C}

\author{
${ }^{1}$ Department of Chemistry, Michael Okpara University of Agriculture, Umudike, Abia State, Nigeria \\ ${ }^{* 2}$ Department of Industrial Chemistry, Madonna University, Elele, Rivers State, Nigeria \\ ${ }^{3}$ Department of Pure and Industrial Chemistry, Nnamdi Azikiwe University, Awka, Anambra State, Nigeria \\ *Corresponding Author Email: chimobitochi@gmail.com
}

\begin{abstract}
This study examined the physicochemical parameters of fish pond water to ascertain if they pose any risk to the environment after disposal. Water samples were collected from metallic, tarpaulin and concrete ponds from Anambra, Imo and Lagos states, Nigeria and analysed for minerals and physicochemical parameters using standard analytical methods. The results obtained were as follows; $\mathrm{pH} 6.30 \pm 0.06-6.94 \pm 0.01$, turbidity $40.00 \pm 0.01-315.00 \pm 1.73$ NTU, TSS 324.00 $\pm 9.59-1346.00 \pm 20.53 \mathrm{mg} / \mathrm{L}$, TDS $24.2 \pm 2.20-45.6 \pm 17.2 \mathrm{mg} / \mathrm{L}$, hardness $18.6 \pm 3.9-24.3 \pm 3.80$, phosphate $0.12 \pm 0.01-0.23 \pm 0.01$, nitrate $0.42 \pm 0.02-1.17 \pm 0.01$, BOD $1.43 .33 \pm 1.41-577.67 \pm 2.8$, DO $27.67 \pm 1.41-$ $57.67 \pm 0.02, \mathrm{Zn} 0.12 \pm 0.03-0.92 \pm 0.02, \mathrm{Cu} 0.18 \pm 0.03-0.53 \pm 0.01$, Fe $0.24 \pm 0.02-0.55 \pm 0.02$ and $\mathrm{Ca} 0.19 \pm 0.02-$ $0.51 \pm 0.02$. The results varied from one pond to another depending on the residence time of the samples and the nature of the pond. All parameters were within the established limit for effluent disposal except biochemical oxygen demand (BOD)and dissolved oxygen (DO).
\end{abstract}

\section{DOI: https://dx.doi.org/10.4314/jasem.v25i2.17}

Copyright: Copyright $\odot 2021$ Mgbemena et al. This is an open access article distributed under the Creative Commons Attribution License (CCL), which permits unrestricted use, distribution, and reproduction in any medium, provided the original work is properly cited.

Dates: Received: 12 December 2020; Revised: 26 January 2021; Accepted: 12 February 2021

Keywords: Physicochemical parameters, Fish pond, Aquaculture, Freshwater, Fish

Aquaculture plays a significant role in food security and adequate nutrition (FAO, 2020). It supplies fish which is a major and cheaper source of essential protein in human diet. However, uncontrolled aquaculture activities especially land-based aquaculture may adversely affect the environment (Masaba et al., 2019). A number of chemicals including pharmaceuticals are used in aquaculture to improve water quality, prevent aquatic plant invasion, phytoplankton bloom and diseases. These chemicals include fertilizers, liming materials, oxidants, coagulants, algicides and herbicides, probiotics, pesticides, and heavy metals (Boyd and Massaut, 1999). Furthermore, aquaculture activities generate large amount of organic matter, nutrients and suspended solids from organic input of fish feeds (Amankwaah et al., 2014). Fish ponds are also reservoirs of mineral components of fish feeds (Maule et al., 2007). The impact on the immediate vicinity of discharge point source includes air pollution from foul odour, eutrophication, increased oxygen depletion and turbidity of receiving water channels (Ilechukwu et al., 2020; Naylor et al., 2000; Ilechukwu and Okonkwo, 2012). Antibiotics from pond effluents may also lead to the development of antibiotic resistant strains (Ajewole et al., 2020). The effects of fish pond effluent on freshwater environment have been reported (Abbas and Al-Seria, 2020; Yoboué et al., 2020; Amankwaah et al., 2014; Buschmann et al., 1996). A recent study in Nigeria evaluated the impact of effluent discharge from a medium-scale fish farm on a stream in Ijebu-ode, Ogun State (Famoofo and Adeniyi, 2020). Nigeria has embraced agriculture as one of the economy diversification strategies. This has led to the noticeable increase in fish farming with the resultant corresponding increase in the volume of discharged fish pond water from land-based aquafarms. Majority of these ponds are located in urban and semi-urban areas to maximise sales and productivity leading to the disposal of the fish pond water in storm water channels, open fields and street roads. Fish pond water is also an effluent from agricultural processes (Yoboué et al., 2020; Amankwaah et al., 2014). This is why it is essential that the physicochemical quality and mineral constituents of fish pond water is routinely examined to ensure that it meets set regulatory criteria that pose no harm to the environment after disposal. The aim of this study was to determine the physicochemical properties and mineral constituents of fish pond water. The minerals considered were those that are constituents of fish feeds. The conclusion drawn from the study is expected to aid in sustainable aquaculture management.

\section{MATERIALS AND METHODS}

Sample Collection: The fish ponds used for this study are located in Anambra, Imo and Lagos states in Nigeria.Samples were collected July, 2019. Prior to sample collection, all the sampling bottles (1L) were thoroughly washed, dried and rinsed with the same water to be collected in the ponds. The pond 
description and the residence time of the pond water are shown in Table 1.

Table 1: Pond description and residence time of pond water at sampling

\begin{tabular}{|c|c|c|c|c|}
\hline $\mathbf{S} / \mathbf{N}$ & $\begin{array}{l}\text { Sample } \\
\text { Code }\end{array}$ & $\begin{array}{l}\text { Sample Location } \\
\text { (State) }\end{array}$ & $\begin{array}{l}\text { Pond } \\
\text { Description }\end{array}$ & $\begin{array}{l}\text { Residence } \\
\text { Time }\end{array}$ \\
\hline 1 & $\mathrm{~A}$ & Imo & Metallic tank & 1 day \\
\hline 2 & B & Imo & Metallic tank & 2 days \\
\hline 3 & $\mathrm{C}$ & Imo & Tarpaulin tank & 2 days \\
\hline 4 & $\mathrm{D}$ & Lagos & Tarpaulin tank & 3 days \\
\hline 5 & $\mathrm{E}$ & Lagos & Plastic tank & 1 day \\
\hline 6 & $\mathrm{~F}$ & Lagos & Tarpaulin tank & 1 day \\
\hline 7 & $\mathrm{G}$ & Lagos & Metallic tank & 2 days \\
\hline 8 & $\mathrm{H}$ & Lagos & Concrete & 2 days \\
\hline 9 & I & Anambra & Concrete & 3 days \\
\hline
\end{tabular}

Physicochemical Analysis: The $\mathrm{pH}$, total suspended and dissolved solids, dissolved oxygen, biochemical oxygen demand, turbidity, phosphate and nitrate concentration in the samples were determined using standards methods (APHA, 1998).

Mineral Analysis: Fifty millilitres $(50 \mathrm{~mL})$ of each water sample were transferred to a digestion flask and digested with $10 \mathrm{~mL}$ aqua regia $\left(\mathrm{HNO}_{3} / \mathrm{HCl} ; 1: 3 \mathrm{v} / \mathrm{v}\right)$ on a thermostated hot plate at $150^{\circ} \mathrm{C}$. Deionised water was added to rinse the flask after cooling. The sample was filtered and the filtrate made up to $50 \mathrm{~mL}$ with deionised water. The samples were analysed for zinc, copper, calcium, manganese and iron with Varian AA240 atomic absorption spectrophotometer (AAS). Statistical Analysis: All analysis was done in triplicates and reported as mean \pm standard deviation. Pearson's correlation was used to determine the relationship between the physicochemical parameters.

\section{RESULTS AND DISCUSSION}

The physicochemical parameters of the fish pond water samples are presented in Table 2 . The $\mathrm{pH}$ of the samples was between $6.30 \pm 0.06$ and $6.94 \pm 0.01$ and was slightly acidic. The least $\mathrm{pH}$ values were observed in samples from concrete ponds. Pond water released into the environment at this $\mathrm{pH}$ is not likely to pose any harm to the environment. $\mathrm{pH}$ variations may be as a result of the initial $\mathrm{pH}$ of the water before introduction into the pond. The turbidity of the samples was between $40.00 \pm 0.01$ and $315.00 \pm 1.73$ NTU. Highly turbid waters require some treatment before release into environment. The high turbidity of some of the samples may be due to poor housekeeping. Ponds that are always washed and kept clean will be less turbid. Turbidity may also be as a result of over population. Introduction of feeds and metabolic activities of fishes in the pond such as excretion contribute to the turbidity of fish pond water. Release of high turbid fish pond water into the environment destroys the aesthetic nature of the environment.

Table 2: Physicochemical parameters of the fish pond water samples

\begin{tabular}{|c|c|c|c|c|c|c|c|c|c|}
\hline $\mathbf{F}$ & $\begin{array}{l}\text { Sample } \\
\text { A } 1 \\
\text { metallic }\end{array}$ & $\begin{array}{l}\text { Sample } \\
\text { B 2 } \\
\text { metallic }\end{array}$ & $\begin{array}{l}\text { Sample } \\
\text { C 2 } \\
\text { Tarpaulin } \\
\end{array}$ & $\begin{array}{l}\text { Sample } \\
\text { D } 3 \\
\text { Tarpaulin }\end{array}$ & $\begin{array}{l}\text { Sample } \\
\text { E } 1 \\
\text { Tarpaulin } \\
\end{array}$ & $\begin{array}{l}\text { Sample } \\
\text { F } 1 \\
\text { Tarpaulin }\end{array}$ & $\begin{array}{l}\text { Sample } \\
\text { G2 } \\
\text { Metallic } \\
\end{array}$ & $\begin{array}{l}\text { Sample } \\
\text { H } 2 \\
\text { Concrete } \\
\end{array}$ & $\begin{array}{l}\text { Sample } \\
\text { I } 3 \\
\text { Concrete }\end{array}$ \\
\hline $\mathrm{oH}$ & $6.97 \pm 0.02$ & $70 \pm 0.06$ & $6.83 \pm 0.05$ & $6.94 \pm 0.02$ & $6.73 \pm 0.05$ & $6.59 \pm 0.16$ & $6.50 \pm 0.03$ & $6.30 \pm 0.06$ & 0.01 \\
\hline & & & & & & & & & \\
\hline $\mathrm{Ph}$ & ND & ND & $\mathrm{ND}$ & & NI & NI & & N. & \\
\hline & & & & & & & & & \\
\hline D & & & & & & & & & \\
\hline $\mathrm{BO}$ & 16 & & 1 & & & & & & \\
\hline & & & & & & & & & 90 \\
\hline TSS & & & & 0.53 & & & & & \\
\hline 7 & 28 & \pm 3.15 & 2 & \pm 17.20 & $26.3 \pm 2.70$ & \pm 2.20 & & $30 \pm 2.58$ & $43.2 \pm 16.4$ \\
\hline
\end{tabular}

The total suspended solids (TSS) in the samples were between $324 \pm 9.59-1346 \pm 20.53 \mathrm{mg} / \mathrm{L}$ while the values of total dissolved solids (TDS) were between $24.2 \pm 2.20-45.6 \pm 17.2 \mathrm{mg} / \mathrm{L}$. The highest concentration of solids was in samples that have stayed three days in the pond (samples I and D). Solids in the pond water are usually from fish meal (Omitoyin et al., 2005). Variations in the fish meals may have been responsible for the difference in the solid contents of the ponds. The solids are within limits for effluent discharge into the environment (DPR, 2002; FEPA, 1991). There was a strong positive correlation between the residence time of the samples and TDS $(+0.96)$ and TSS (+0.98) respectively indicating that the concentration of solids in fish pond water increases with the duration of water in the pond. The values of water hardness for the samples were between $18.6 \pm 3.93-24.3 \pm 3.80 \mathrm{mg} / \mathrm{L}$. No particular trend was observed in the water hardness of the samples. The hardness of the pond water may have been that of the water before introduction into the pond and this confirms that aquaculture activities may have negligible effects on hardness of pond water. The water hardness of the samples was within the recommended values for effluent discharge into the environment (DPR, 2002; FEPA, 1991). The phosphate concentration in the samples was between $0.12 \pm 0.01-0.23 \pm 0.01 \mathrm{mg} / \mathrm{L}$ while the nitrate concentration was between $0.42 \pm 0.02$ $1.17 \pm 0.01 \mathrm{mg} / \mathrm{L}$. The concentration of both phosphate and nitrate in the samples were within the recommended limits for disposal into the environment. It may also be an indication that aquaculture activities introduce minimal phosphate and nitrate into the environment. These nutrients were higher in samples from Lagos state and may have been in the samples prior to introduction into the ponds. The weak positive correlation between residence time of the samples and 
phosphate $(+0.40)$ and nitrate $(+0.04)$ respectively confirms that aquaculture activities does not significantly introduce these nutrients into the ponds and the nitrate sources may be from the metabolic activities of the fishes in the pond (Chen et al., 2017; Dolomatov et al., 2011). The sample BOD values were between $143.33 \pm 1.41-577.67 \pm 2.80 \mathrm{mg} / \mathrm{L}$. Sample E has the highest concentration and this is not surprising considering that it has the highest concentration of nitrate. There is also a moderate positive correlation $(+0.64)$ between BOD and nitrate concentration in the samples. The BOD levels in the entire samples were higher than the permissible limit by FEPA which is 30 $\mathrm{mg} / \mathrm{L}$ and will require treatment before disposal into the environment (FEPA, 1991). The dissolved oxygen values in the samples were between $27.67 \pm 1.41-$ $57.27 \pm 0.02 \mathrm{mg} / \mathrm{L}$. Dissolved oxygen is necessary for optimum survival of aquatic organisms. Sample A has the highest dissolved oxygen concentration; while this may be attributed to the fact that it has been introduced in the pond for 24 hours, it is significant to observe that sample $\mathrm{E}$ and $\mathrm{F}$ have low DO concentration despite being in the pond for 24 hours. This may be attributed to the quality of Lagos samples before introduction into the pond. Microbial activities consume DO in aquatic environment. However, these results show that if these fish pond water were disposed after three days, the DO level would not be within acceptable limit for effluent disposal (DPR. 2002).

Table 3: Pearson correlation of the physicochemical parameters of the fish pondwater

\begin{tabular}{lllllllllll}
\hline & $p H$ & Turbidity & Phosphate & Nitrate & DO & BOD & Hardness & TSS & TDS & $R T$ \\
\hline pH & 1 & & & & & & & & & \\
Turbidity & -0.04203 & 1 & & & & & & & & \\
Phosphate & 0.463596 & -0.40665 & 1 & & & & & & & \\
Nitrate & -0.13377 & -0.36321 & 0.414295 & 1 & & & & & & \\
DO & -0.01013 & -0.16524 & -0.21981 & 0.055928 & 1 & & & & & \\
BOD & 0.334798 & -0.41402 & 0.345064 & 0.638779 & -0.16958 & 1 & & & \\
Hardness & 0.406928 & -0.11108 & 0.100108 & -0.22823 & 0.203815 & 0.339192 & 1 & & & \\
TSS & -0.13966 & 0.207175 & 0.464668 & 0.093696 & -0.38261 & -0.31345 & -0.53426 & 1 & & \\
TDS & -0.04984 & 0.217809 & 0.524777 & 0.149247 & -0.42464 & -0.19934 & -0.48173 & 0.989966 & 1 & \\
RT & -0.24701 & 0.244466 & 0.40303 & 0.038295 & -0.45376 & -0.33051 & -0.46104 & 0.979551 & 0.964588 & 1 \\
\hline
\end{tabular}

$R T=$ Residence time

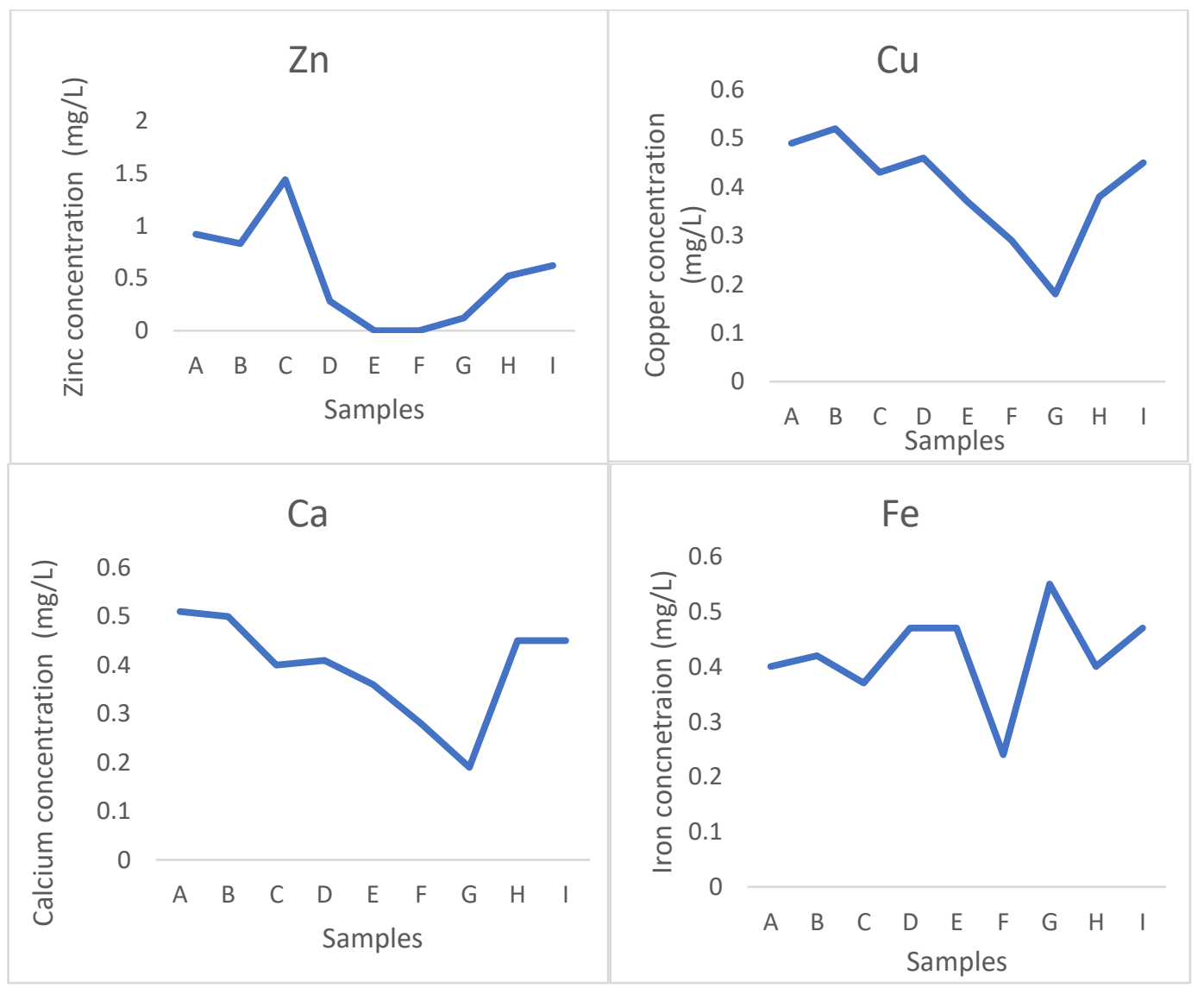

Fig 1: Mineral concentration in the fish pond samples 
Mineral Analysis: The concentration of zinc in the samples was between $0.12 \pm 0.03-0.92 \pm 0.02 \mathrm{mg} / \mathrm{L}$. Zinc was not detected in samples $\mathrm{E}$ and $\mathrm{F}$; both ponds from Lagos state. Copper concentration in the samples was between $0.18 \pm 0.03-0.53 \pm 0.01 \mathrm{mg} / \mathrm{L}$. copper was detected in all the samples. The concentration of iron and calcium in the samples was between $0.24 \pm 0.02-$ $0.55 \pm 0.02$ and $0.19 \pm 0.02-0.51 \pm 0.02 \quad \mathrm{mg} / \mathrm{L}$ respectively. Manganese was found in only sample I from Anambra state at the concentration of $0.24 \pm 0.01$ $\mathrm{mg} / \mathrm{L}$. The mineral concentration in the water sample before introduction into the ponds may have contributed more than aquaculture activities to the mineral concentration in the pond water. The concentration of all the minerals were within the recommended limit for effluent disposal.

Conclusion: The physicochemical parameters and the minerals determined in the fish pond water were all within permissible limits for release into the environment except biochemical oxygen demand (BOD) and dissolved oxygen (DO). Recommendations include frequent cleaning of fish ponds, controlled disposal of fish pond water and reuse of fish pond water especially for fertigation and in hydroponics.

\section{REFERENCES}

Abbas, UR; Al-Seria, MHM (2020). The effect of fish culture ponds on the benthic invertebrate community in Tigris River, Iraq. Plant Arch, 20:1873-1884

Ajewole, OA; Ikhimiukor, OO; Adewolo, OO (2020). Heavy metals $(\mathrm{Cu}$ and $\mathrm{Zn})$ contamination of pond sediment and co-occurrence of metal and antibiotic resistance in Escherichia coli from Nigerian aquaculture. Int. J. Environ. Stud.https://doi.org/10.1080/00207233.2020.1804741

Amankwaah, D; Cobbina, SJ; Tiwaa, YA; Bakobie, N; Millicent, EAB (2014). Assessment of pond effluent on water quality of the Asuofia stream, Ghana. Afr. $J$. Environ. Sci. Technol. 8(5): 306-311

APHA (1998). Standard Methods for the Examination of Water and Wastewater. 20th ed. Washington: American Public Health Association.

Boyd, CE; Massaut, L (1999). Risks associated with the use of chemicals in pond aquaculture. Aquac. Eng. 20: 113132

Buschmann, AH; Lopez, DA; Medina, A (1996). A review of environmental effects and alternative production strategies of marine aquaculture in Chile. Aquac. Eng. 15(6): 391-421

Chen, R; Deng, M; He, X; Hou, J (2017). Enhancing nitrate removal from freshwater pond by regulating carbon/nitrogen ratio. Front Microbiol. 8: 1712

Dolomatov, SI; Shekk, PV; Zukow, W; Kryukova, MI (2011). Features of nitrogen metabolism in fishes. Rev. Fish Biol. Fish. 21: 733-737
DPR (2002). Environmental Guidelines and Standards for the Petroleum Industry in Nigeria (EGASPIN), Nigeria. Department of Petroleum Resources.

Famoofo, OO; Adeniyi, IF (2020). Impact of effluent discharge from a medium -scale fish farm on the water quality of Odo-Owa stream near Ijebu-Ode, Ogun State, Southwest Nigeria. Appl. Water Sci. 10:68

FAO (2020). Fishery and Aquaculture Statistics. Global production by production source 1950-2018(FishstatJ). In: FAO Fisheries and Aquaculture Department [online]. Rome. Updated 2020.www.fao.org/fishery/statistics/software/fishstatj/ en

FEPA (1991). Guidelines and standards for environmental pollution control. Federal Environment Protection Agency 27 PP 20.

Ilechukwu, I; Olusina, TA; Echeta, OC (2020). Physicochemical analysis of water and sediments of Usuma Dam, Abuja, Nigeria. Ovidius University Annals of Chemistry 31(2): 80-87

Ilechukwu, I; Okonkwo, C (2012). Heavy metals and physicochemical parameters of potable water in Nnewi, Anambra State, Nigeria. Arch. Appl. Sci. Res. 4(5): 2094-2097

Masaba, J; Wangila, B; Lung'ayia, H (2019). Water quality status of a stream receiving fish pond discharge using physicochemical indicators in Lake Victoria catchment, Kenya. Int. J. Fish. Aquat. 7(6): 260-267

Maule, AG; Gannam, AL; Davis, JW (2007). Chemical contaminants in fish feeds used in federal salmonid hatcheries in the USA. Chemosphere, 67: 1308-1315.

Naylor RL; Goldburg RJ; Primavera JH; Kautsky N; Beveridge MCM; Clay J; Folke C; Lubchenco J; Mooney H; Troell M (2000). Effect of aquaculture on world fish supplies. Nature 405:1017-1024.

Omitoyin, BO; Adesehinwa, OK; Edibite, LI (2005). Reproductive performance and serum biochemistry of female Clariasgariepinus brood stock raised in pond effluent water. Trop.Subtrop.5:117-122.

Yoboué, KP; Quattara, NI; Berté, S; Aboua, BRD; Coulibaly, JK; Kouamélan, EP (2020). Structure of benthic macroinvertebrates population in an area of Mopoyem Bay (Ebrie Lagoon, Côte d'Ivoire) exposed to the discharge of a fish farm effluents. Environ. Monit. Assess. 192:203 